\title{
An Adapted Dialogic Reading Program for Turkish Kindergarteners from Low Socio-economic Backgrounds
}

\author{
Cevriye Ergül ${ }^{1}$, Gözde Akoğlu², Ayse D. Sarıca ${ }^{3}$, Gökçe Karaman ${ }^{1}$, Mümin Tufan ${ }^{4}$ Zeynep Bahap-Kudret ${ }^{1}$, Zülfikar \\ Deniz ${ }^{1}$ \\ ${ }^{1}$ Faculty of Educational Sciences, Ankara University, Ankara, Turkey \\ ${ }^{2}$ Faculty of Health Sciences, Kırıkkale University, Kırıkkale, Turkey \\ ${ }^{3}$ Buca Faculty of Education, Dokuz Eylül University, İzmir, Turkey \\ ${ }^{4}$ Faculty of Education, Gazi University, Ankara, Turkey \\ Correspondence: Cevriye Ergül, Faculty of Educational Sciences, Ankara University, Cemal Gürsel Cad. 06590, Cebeci, \\ Ankara, Turkey.
}

Received: March 31, 2016 Accepted: April 12, $2016 \quad$ Online Published: April 19, 2016

doi:10.11114/jets.v4i7.1565 URL: http://dx.doi.org/10.11114/jets.v4i7.1565

\begin{abstract}
The study aimed to examine the effectiveness of the Adapted Dialogic Reading Program (ADR) on the language and early literacy skills of Turkish kindergarteners from low socio-economic (SES) backgrounds. The effectiveness of ADR was investigated across six different treatment conditions including classroom and home based implementations in various combinations in six different schools. The study group consisted of 112 kindergarteners, their teachers $(\mathrm{n}=6)$ and their parents $(\mathrm{n}=56)$. The treatment lasted for seven weeks. In this quasi-experimental study, children were pre- and post-tested on measures of language and early literacy. Data were analyzed using ANCOVA, a mixed design ANOVA, and a single factor ANOVA. Results revealed that ADR was effective in promoting the language and early literacy skills of kindergarteners in treatment conditions including home based intervention. Intensity of treatment was also found to play a major role in child performance in that, ADR implemented in only one setting (either at home or in the classroom) promoted higher achievement in language while ADR implemented in both settings promoted higher achievement in early literacy. The findings are discussed within the context of early childhood education programs in Turkey.
\end{abstract}

Keywords: the adapted dialogic reading program, language, early literacy, kindergarteners at risk

\section{Introduction}

\subsection{The Problem}

Many recent studies investigating the factors that impact reading achievement focus on early literacy. This is primarily due to the fact that a significant number of children start school unequipped with basic early literacy skills (Hudson \& Test, 2011) while a majority of these children often have difficulty in learning to read and fall behind their peers throughout their school lives (McCardle, Scarborough, \& Catts, 2001; Snow, Burns, \& Griffin, 1998; Whitehurst \& Lonigan, 2001). Early literacy is generally defined as "the literacy-related knowledge, skills and attitudes that establish the foundation for the conventional forms of reading and writing" (Sulzby \& Teale, 1991; Uzuner, 1997; Whitehurst \& Lonigan, 1998). It includes several skill areas including oral language and vocabulary, phonological awareness, print awareness and letter knowledge (Aarnoutse, Leeuwe, \& Verhoeven, 2005; Burns, Griffin, \& Snow, 1999; Dickinson \& McCabe, 2001; Elliott \& Olliff, 2008; Spira, Bracken, \& Fischel, 2005). Previous research established a significant relationship between early literacy and later academic success (Cabell, Justice, Konolda, \& McGinty, 2011; Nelson, 2005; Vellutino, Scanlon, \& Lyon, 2003) and these skills were found to strongly predict elementary school reading performance (National Early Literacy Panel, 2009; Spira et al., 2005). Others also showed that reading achievement in elementary school was strongly related to vocabulary knowledge (Beck, McKeown, \& Kucan, 2002; Hart \& Risley, 2003; Liu et al., 2010; Verhoeven \& Perfetti, 2011), phonological awareness (Ehri, Nunes, Stahl, \& Willows, 2001; Kjeldsen, Karna, Niemi, Olofsson, \& Witting, 2014; Yopp \& Yopp, 2000), print awareness (Farver, Nakamoto, \& Lonigan, 2007; Lesiak, 1997; Pullen \& Justice, 2003) and letter knowledge (Badian, 1995; Denton \& West, 2002; Evans, Bell, Shaw, Moretti, \& Page, 2006; Leppanen, Niemi, Aunola, \& Nurmi, 2006) in the preschool years. Therefore, it seems knowledgeable to claim that in order to build a foundation for later reading success, it is important to support children's early literacy development. 


\subsection{Purpose of the Study and Research Questions}

Preschool education in Turkey is criticized for its limited focus on early literacy (Deretarla-Gül \& Bal, 2006; Ergül, Akoğlu, Sarıca, Tufan, \& Karaman, 2015; Ergül et al., 2014). Classrooms generally lack the necessary physical features such that activity/learning centers do not exist or are of low-quality, and the variety of classroom activities are limited to independent play with toys or simple painting (Deretarla-Gül \& Bal, 2006). Preschool teachers in general, lack an awareness of the developmental importance of early literacy skills and fail to make use of strategies to support the early literacy skills of their students. When they do feel the need to support early literacy, they tend to stick to concept teaching, line drawing (as a writing exercise), and read-alouds that are considered insufficient strategies for supporting early literacy. Although all teachers read-aloud on a regular basis (3-4 times a week), they do not engage in effective techniques including interactive reading or dialogic reading (DR) (Ergül et al., 2014). In addition, read-alouds are only conducted as a whole class activity and last nearly 10-15 minutes with only a few questions asked by the teacher before and after reading with very limited interaction with the students. Also, contrary to effective early literacy exercises, teachers do not allow for any interruptions during reading (Ergül et al., 2015).

The single study investigating the effects of an evidence based reading method in Turkey was conducted by Kotaman (2008), investigating the effects of DR on high SES (socio-economic status) preschoolers' receptive vocabulary and reading attitudes. The study entailed a 7 -week DR program with children of 40 parents of whom were mostly university graduates, and a significant improvement was found in children's receptive vocabulary and reading attitudes. Despite the favorable results reported by Kotaman, no studies to date have comprehensively investigated the effects of DR in Turkey. The authors believed that such investigation should yield findings from disadvantaged groups shown to be at risk for reading difficulties in elementary grades (e.g. Bursuck \& Damer, 2007; Cabell et al., 2011; Dickinson \& McCabe, 2001; Stevenson \& Fredman, 1990) and findings regarding the type of setting(s) where children benefit from DR the most (i.e. home, classroom and/or both).

This study investigated the effects of a DR intervention on the language and early literacy skills of kindergarteners who were at-risk due to their low SES backgrounds. The authors made certain modifications on DR to include print and phonological referencing as described in previous studies (e.g., Arnold, Lonigan, Whitehurst \& Epstein, 1994; Justice \& Ezell, 2002; Justice, Kaderavek, Bowles, \& Grimm, 2005; Whitehurst, Arnold et al., 1994) to promote child progress in other key early literacy domains along with additional oral language exercises in order to assure a higher level of school readiness. The effects of this Adapted Dialogic Reading Intervention (ADR) on language and early literacy skills of children were investigated across six treatment (five experimental and one control) conditions differing in type of setting (home, classroom and both) and group size (small group with 5-8 children and large group - whole class). In line with this general aim, the following research questions were proposed: (i) Were there any differences among the ADR groups and the control group on the posttest scores of child language, print awareness, and phonological awareness measures while controlling for pretest differences? (ii) Were there any differences in teacher and parent ADR behaviors from pre- to posttest? (iii) Was ADR found socially valid by preschool teachers and parents?

\subsection{Related Literature}

\subsubsection{Early Literacy Skills and Joint Reading}

Pioneering studies in developing early literacy skills mostly advocated for adult-child joint reading. These studies showed that joint reading activities contributed significantly to children's receptive and expressive vocabulary, and that the outcomes did not change when the effects of parent education or child analytic intelligence were controlled (Senechal, LeFevre, Thomas, \& Daley, 1998). Repeated joint reading activities offer children opportunities to acquire new words and use them in daily verbal communication (Horst, Parsons, \& Bryan, 2011; McLeod \& McDade, 2011; Robbins \& Ehri, 1994), where as Senechal and Cornell (1993) stated that even one single reading activity contributes to child receptive vocabulary. In addition to repeated reading activities, those that involve adults using instructive behaviors are more effective in developing children's language skills. Children who answer questions about the target words learn and produce more words compared to children who only repeat the words and point to their pictures in the book (Senechal, 1997; Senechal, Thomas, \& Monker, 1995; Walsh \& Blewitt, 2006). In sum, child's active participation in joint reading activities and increased child-adult interaction positively affect the learning process.

\subsubsection{Dialogic Reading (DR)}

DR is a method of interactive adult-child joint reading activity developed by Whitehurst and colleagues to support child language and early literacy skills (Whitehurst et al., 1988; Whitehurst, Arnold et al., 1994; Whitehurst, Epstein et al., 1994). During DR, adults and children swap roles and with the support of the adult, the child learns to become a story narrator. The adult is an active listener and questioner. S/he supports the child's learning by giving her opportunities to talk, asking questions, explaining unknown words and repeating and expanding her responses (Justice \& Pullen, 2003; Whitehurst, Arnold et al., 1994). 
As a well-validated method, DR is based on three basic principles that aim to develop children's language and listening comprehension skills (Hargrave \& Senechal, 2000; Justice \& Pullen, 2003; Morgan \& Meier, 2008; Whitehurst, Arnold et al., 1994). These include encouraging children to participate in the reading activity, giving feedback on what they say, and setting topics to talk about by choosing books that reflect age-appropriate language skills and child interests. In order to ensure active child participation in book reading, Whitehurst and colleagues defined several types of prompts to initiate children's talk during DR using the acronym CROWD (Completion, Recall, Open-ended, Wh- questions, Distancing). These include asking students to complete a statement or sentence in the story (Completion), answer questions about the characters or events (Recall), describe events shown in pictures (Open-ended questions), name an object or action shown in pictures (Wh- questions) and link the story to their own lives (Distancing). This supports children's language and listening comprehension skills, deepens their interest in the story, improves their vocabulary and attention to detail, offers them an opportunity to use language, and make connections between stories and real life. DR also defines how to provide corrective feedback and expand children's responses using the acronym PEER (Prompt, Evaluate, Expand, Repeat). It involves initiating a talk (Prompt), evaluating accuracy of children's responses (Evaluate), expanding these responses by using appropriate words and sentence structures (Expand), and asking children to repeat the corrected or expanded responses (Repeat). Gradually, children's attention, story-based information, and vocabulary improve (Whitehurst, Arnold et al., 1994).

Studies have shown that DR supports language development by way of increasing children's receptive and expressive vocabulary. These studies investigated the effects of DR in different settings and pointed out that DR interventions conducted in the home, classroom or home+classroom conditions around 6-8 weeks resulted in substantial language gains for preschoolers and that these gains were significantly higher in conditions including parent involvement (Hargrave \& Senechal, 2000; Lever \& Senechal, 2011; Lonigan \& Whitehurst, 1998; Reese, Leyva, Sparks, \& Grolnick, 2010; Whitehurst, Arnold, et al., 1994). DR was shown to increase children's print and phonological awareness skills as well when adults reference to print and sounds while reading. For instance, Ezell and Justice (2000) and Justice and Ezell (2002) made adults reference to print in different ways while reading, and found this to increase children's awareness of print concepts, letters, words, and the relationship between print and verbal language. Others found that when parents emphasized the phonological features of words during DR, children displayed significant improvement in phonological awareness skills by the end of the 6-10-week programs (Arnold, Lonigan, Whitehurst, \& Epstein, 1994; Chow, McBride-Chang, \& Cheung, 2010; Justice, Kadevarek, Bowles, \& Grimm, 2005; Stadler \& McEvoy, 2003; Whitehurst, Arnold et al., 1994). Lastly, DR was proved to develop children's positive attitudes towards reading through active involvement in the process and having a good time with the adult (Kotaman, 2008; Sperling \& Head, 2002). Taken together, many studies revealed that DR significantly improves receptive and expressive language skills as well as print and phonological awareness in young children (Justice \& Pullen, 2003; Justice, Pullen, \& Pence, 2008; Mol, Bus, de Jong, \& Smeets, 2008).

Although several intervention studies have indicated that young children could benefit significantly from a dialogic reading intervention, parents or teachers seem to rarely employ DR strategies in their routine reading activities with children (Huebner, 2000; Huebner \& Meltzoff, 2005). As reported by Huebner (2000), adults usually read the story directly without facilitating any interaction with the child. In short, they just read and the child listens. However, when a brief training is provided, parents and teachers can change their reading behaviors and increase the frequency of their dialogic reading behaviors dramatically (Justice et al., 2008; Mol et al., 2008). Therefore, it is important to include both parents and teachers in any DR intervention.

\subsubsection{Socio-economic Disadvantages and Children's Book Reading Experiences}

Strong correlations have been reported in the literature between socioeconomic status (SES) and academic achievement (Bursuck \& Damer, 2007; Cabell et al., 2011; Dickinson \& McCabe, 2001; Stevenson \& Fredman, 1990) where children coming from lower SES families mostly started school lacking the early literacy skills necessary for school success (Teale, 1986; Whitehurst, Arnold et al., 1994). Young children's book reading experiences are reported to play an important role in this (Whitehurst, Arnold et al., 1994). Adams (1990, p. 85) found that a middle SES child spends between 1000-1700 hours of one-to-one reading activities with parents prior to starting school, while a lower SES child spends an average of 25 hours engaged in similar activities. In addition, lower SES mothers were shown to display fewer instructive behaviors while reading than middle and upper SES mothers. Similarly, it has been reported that the majority of children in neighborhoods in which low SES families are predominant have none or only a few books at home, while conversely, children in neighborhoods of high SES own usually over 50 (Al Otaiba, Lewis, Whalon, Dyrlund, \& McKenzie, 2009; Niklas \& Schneider, 2013; Ren \& $\mathrm{Hu}, 2011$; van Steensel, 2006). These studies imply that the home reading experiences of preschoolers are affected by their SES, with low SES being more vulnerable to future academic failure. Therefore, in order to mitigate the effects of low SES and reduce the gap in the acquisition of early literacy skills, it is important to add parent training in DR into the equation (Farkas \& Beron, 2004; Fielding-Barnsley \& Purdie, 2003; Huebner, 2000; NAEYC, 2009). 


\section{Method}

\subsection{Setting}

This study utilized a quasi-experimental research design in order to investigate the effects of ADR across six treatment groups. Each group consisted of kindergarteners attending the same kindergarten class, making up a total of six kindergarten classes chosen from among the schools located in the low SES neighborhoods of Ankara, the capital of Turkey. The selected schools which were half day programs had similar child profiles, educational environments, and resources. The class sizes of the participating classrooms ranged between 14 and 24 . The teachers of these six classrooms conducted read-alouds 3-4 times a week. The classrooms were assigned to one of the five treatment and one no-treatment (control) conditions randomly. Table 1 summarizes the major characteristics of each group.

Table 1. The Characteristics of the Groups

\begin{tabular}{|c|c|c|}
\hline Treatment Condition & $n$ & Content \\
\hline 1. Whole Group (WG) & 15 & ADR was implemented as a whole-class activity in the classroom. \\
\hline $\begin{array}{l}\text { 2. Whole \& Small } \\
\text { (WSG) }\end{array}$ & 21 & $\begin{array}{l}\text { ADR was implemented both as a whole-class and small group } \\
\text { activity in the classroom. }\end{array}$ \\
\hline $\begin{array}{l}\text { 3. Whole Group \& Home } \\
\text { (WGH) }\end{array}$ & 24 & $\begin{array}{l}\text { ADR was implemented as a whole-class activity in the classroom } \\
\text { and at home by parents. }\end{array}$ \\
\hline $\begin{array}{l}\text { 4. Whole \& Small Group \& } \\
\text { Home (WSGH) }\end{array}$ & 14 & $\begin{array}{l}\text { ADR was implemented as both a whole-class and small group } \\
\text { activity in the classroom and at home by parents. }\end{array}$ \\
\hline 5. Home $(\mathrm{H})$ & 18 & ADR was implemented at home by parents. \\
\hline 6. Control $(\mathrm{C})$ & 20 & $\begin{array}{l}\text { Routine book reading practices were conducted in the classroom } \\
\text { by the teacher. }\end{array}$ \\
\hline
\end{tabular}

\subsection{Study Group}

The study group consisted of a total of 112 five to six year-old kindergarteners ( 62 girls and 50 boys). The mean age of the children was 69.2 months. All children spoke Turkish as their native language and none had special needs. The study also included the preschool teachers $(n=6)$ and the parents $(n=56)$ of the children. Of the four teachers who conducted ADR, 3 had a bachelor's degree in preschool education and had between 8-13 years of professional teaching experience. The teacher who ran the WSG practices was a vocational high school graduate (child development) with a 29-year professional teaching experience. Teachers of the HG and CG groups (with no in-class treatment) also had a bachelor's degree in preschool education with 8 and 10 years of professional experience, respectively. The majority of the participating mothers displayed characteristics in line with a low SES profile. No significant differences were found among the groups with regard to maternal age $(p=.149)$, maternal education $(p=.563)$ and family monthly income $(p=.067)$. Table 2 shows the demographic characteristics of the participating children and their parents.

Table 2. The Demographic Characteristics of the Participating Children and Their Parents

\begin{tabular}{lllllllllll}
\hline & \multicolumn{2}{l}{ Child gender } & \multicolumn{2}{l}{$\begin{array}{l}\text { Child age } \\
\text { (in months) }\end{array}$} & Maternal age & $\begin{array}{l}\text { Maternal } \\
\text { Education } \\
\text { (in years) }\end{array}$ & \multicolumn{2}{l}{$\begin{array}{l}\text { Monthly Income } \\
\text { (TL) }\end{array}$} \\
\hline Condition & $F$ & $M$ & $X$ & $s d$ & $M$ & $S D$ & $M$ & $S D$ & $M$ & $S D$ \\
\hline Whole Group & 9 & 6 & 69.4 & 4.1 & 33.00 & 4.41 & 9.80 & 4.14 & 1437 & 695 \\
Whole \& Small Group & 9 & 12 & 68.6 & 3.1 & 33.09 & 4.44 & 8.92 & 3.17 & 1325 & 686 \\
Whole Group \& Home & 14 & 10 & 67.2 & 3.9 & 33.89 & 7.76 & 10.60 & 2.89 & 1562 & 712 \\
Whole \& Small Group \& Home & 9 & 5 & 70.8 & 4.4 & 30.50 & 2.81 & 11.00 & 4.59 & 1710 & 718 \\
Home & 7 & 11 & 70.2 & 4.2 & 32.76 & 4.64 & 9.59 & 4.17 & 1215 & 766 \\
Control & 14 & 6 & 69.9 & 3.2 & 29.78 & 3.89 & 9.05 & 3.31 & 1230 & 368 \\
\hline
\end{tabular}

2.3 Measures

The Socio-Demographics Form: This form was developed by the researchers to gather information on child (date of birth, gender, whether they have special needs, etc.), parent (occupation, parental education, number of siblings) and family (monthly income, etc.) demographics. The form was completed by the parents prior to intervention.

The Adapted Dialogic Reading Behaviors Checklist: This measure, developed by the researchers, listed all the ADR behaviors that are expected to be demonstrated by the adult before, during, and after book reading. The before-reading behaviors included items like "attracts child's/children's attention to the activity", "reads the title of the book and points to the title while reading it", and "asks child/children to predict what the story might be about based on the cover picture and the title". During-reading behaviors included items like "explains the meanings of unknown words", "asks child/children to relate words with pictures", "helps child/children guess what will happen on the following page", "asks questions that relate something in the story to the child's/children's daily life", and "verbally expands 
child's/children's responses". Finally, after-reading behaviors included items such as "asks child/children to create an alternative ending to the story" and "asks child/children to summarize the events in the story." The checklist included a total of 38 items based on frequency measures and was used at both pre and posttest to identify the possible differences in parent and teacher ADR behaviors. Content validity of the test was assessed through expert opinions. With a minimum five years of experience in early childhood education teaching and research, 10 experts were consulted on relevance, clarity, objectivity, and applicability on a five-point scale. The test items for which expert opinions reached agreement levels of at least $80 \%$ were included in the checklist.

The Social Validity Survey: This self-administered survey, again developed by the researchers, was used in identifying teacher and parental opinions regarding ADR. The survey included 15 items including 12 statements concerning the effects of ADR on which teachers and parents were asked to indicate their degree of agreement on a five-point scale and 3 open-ended questions involving the difficulties they experienced, the most effective aspects of ADR, and any recommendations regarding the program. The content validity of the survey was assessed through expert opinions. With a minimum five years of experience in early childhood education teaching and research, 10 experts were consulted on relevance, clarity, objectivity, and applicability on a five-point scale. The items for which expert answers reached agreement levels of at least $80 \%$ were included in the survey.

TERVT-Turkish Expressive and Receptive Vocabulary Test: The TERVT is a receptive and expressive vocabulary test for Turkish-speaking children aged 2-12 which includes two subtests: (1) the receptive vocabulary subtest with 104 items that require the identification of the correct picture of a named person, object or event among four pictures, (2) the expressive vocabulary subtest with 80 items that require naming the picture shown. The raw scores are converted to standard scores and the age equivalency level is determined for each subtest. Reliability estimates for the receptive vocabulary showed that test-retest reliability, split-half reliability and the internal consistency coefficients were $.97, .99$ and .99 , respectively, while validity measures showed that its correlation with the WISC-R verbal score was .45 $(p=.001)$ and AGTE .48 ( $p=.001)$. Reliability estimates for the expressive vocabulary showed that test-retest reliability, split-half reliability and the internal consistency coefficients were $.97, .99$, and.98, respectively, while validity measures showed that its correlation with the WISC-R verbal score was .52 ( $p=.001)$ and .51 with the AGTE T ( $p=.001)$ (Gül-Güven \& Kazak-Berument, 2010).

Test of Early Language Development-Turkish (TELD-T): TELD-T is an adaptation of the Test of Early Language Development, $3^{\text {rd }}$ Edition (Hresko, Reid, \& Hammill, 1999) for Turkish speaking children which aims to measure 2-7 year-old children's receptive and expressive language skills. It is an individually administered test with sound psychometric properties. It includes two subtests: receptive language and expressive language. These subtests are comprised of a total of 76 ( 37 for receptive and 39 for expressive) items measuring the semantics, morphology and syntax of language. Some of these items involve pointing to and naming pictures while others require carrying out verbal instructions and verbally answering questions. Reliability measures for the receptive language subtest showed that test-retest reliability, inter-rater reliability and internal consistency coefficients were .96 and .99 , respectively while parallel-forms reliability ranged between .64 and .96 . Validity measures showed that its correlation with the WISC-R verbal score was .66 ( $p=.001)$ and $.76(p=.001)$ with PPVT. Reliability measures for the expressive language subtest showed that the test-retest reliability, inter-rater reliability and internal consistency coefficients were $.93, .99$ and .92 , respectively while parallel-forms reliability ranged between .60 and .97 . Validity measures showed that its correlation with the WISC-R verbal score was .53 ( $p=.001)$ and with PPVT, .73 ( $p=.001)$ (Topbaş \& Güven, 2011).

Print Awareness Test: As no standardized measures of print awareness for the Turkish population were found during the time of the study, a print awareness test was developed by the researchers to assess children's print awareness skills. The test included 15 items regarding conceptual knowledge of writing (distinguishing print and non-print and word and non-word, awareness of some basic features of print like reading from left to right and top to bottom, etc.) and concepts such as letters, words, sentences and punctuation marks. Each correct response was assigned " 1 " point, thus the highest score a child could get on the test was 15 . Content validity of the test was assessed through expert opinions. With a minimum five years of experience in early childhood education teaching and research, 10 experts were consulted on relevance, clarity, objectivity, and applicability on a five-point scale. The test items for which expert opinions reached agreement levels of at least $80 \%$ were included in the test. The KR-20 reliability coefficient for the test was .76.

Phonological Awareness Test: This test was also developed by the researchers for the same reason stated for the print awareness test. It had a total of 18 items assessing children's rhyming and alliteration skills. To assess rhyming, children were shown a card with three illustrations, two of which had the same ending sounds. Following two sample items with corrective feedback, the examiner showed the card and sounded out all words and asked the child to point to or tell the two words that ended with a similar sound. To assess alliteration, children were again shown a card with three illustrations, two of which had the same initial sounds. Following two sample items with corrective feedback, the examiner showed the card and sounded out all words and asked the child to point to or tell the two words with the same initial sounds. The 
words in each item were chosen from among words that were commonly known by Turkish kindergarteners. Each correct response was assigned " 1 " point. Content validity of the test was assessed through expert opinions. With a minimum five years of experience in early childhood education teaching and research, 10 experts were consulted on relevance, clarity, objectivity, and applicability on a five-point scale. The test items for which expert opinions reached agreement levels of at least $80 \%$ were included in the test. The KR-20 reliability coefficient for the test was 87 .

\subsection{Procedures}

The study was conducted in three stages: preparation, the pilot study, and the main study.

\subsubsection{Preparation}

The first step in the preparation phase included book selection to be used during ADR. A group of criteria were determined by the authors which included: (1) appearance and content (page layout, paper quality, number of pages, image quality, theme, story grammar, etc.) and (2) qualities pertaining to effective dialogic reading (few written expressions, many pictures that might serve as springboard for speaking, developed around a theme, acceptable number of unknown words). A total of 6 fiction and 1 non-fiction books met the above criteria. Each book contained about 7-8 new words that were developmentally appropriate for 5-year-olds but unknown to most and 2-3 words that were unknown to only some children. For each book, 10 target words and 1 phoneme (considering the developmental sequence of speech sounds) were determined, and activity booklets were developed. Activity booklets were created to guide teachers and parents during dialogic reading. They included many examples of "wh" and open-ended questions to prompt children to talk, expand their responses, and ways of print and phonological referencing to guide their interaction with child/children while reading.

Meanwhile, the research team (all authors excluding the former author) training in dialogic reading techniques and behaviors was completed by the former author who had previous knowledge and practice with DR. The training included direct instruction and video based corrective feedback in both in-vivo and real home and classroom settings with real child participants.

\subsubsection{The Pilot Study}

DR was piloted by the research team in three kindergarten classrooms from low, middle and high SES backgrounds to identify the potential DR modifications that would fit within the existing education system in Turkey. All pilot implementations were video-recorded and examined/discussed weekly. In addition, weekly meetings were held with the participating classroom teachers in order to obtain their opinions regarding any adaptations they felt were needed in DR. The pilot study was undertaken over a course of 4 weeks, with 1-hour bi-weekly sessions in each class. During the pilot study, DR was also implemented one-to-one with children in the home environment in order to determine any adaptations that were needed for conducting home-implemented DR. All home practices were video-taped to be used in parent trainings. The results from the pilot study were used to shape the adapted DR (frequency of readings, large and small group times, etc.) into the existing program.

\subsubsection{The Main Study}

The participating kindergarten classrooms were randomly assigned to one of the six treatment conditions. All teachers and parents in these classrooms gave informed consent to participate in the study. Teacher and parent trainings and the pretests were conducted during the two week period prior to the study. The pretests included the children, the teachers, and the parents. Each child's testing took approximately two individual sessions with TELD and the Print Awareness Test in one session, TERVT and the Phonological Awareness Test in the other. Teacher and parent trainings were conducted concurrently with the pretests. Trainings were conducted by the researchers in four-hour sessions separately for teachers and parents and focused on early literacy skills and the aims/significance, procedures and expected outcomes of ADR. Sample videos recorded during the pilot study were used during these sessions. In addition, the seven chosen books and the activity booklets prepared for each book were introduced. At the end of this training session, the trainees received the first book and the activity booklet to use in the first week of intervention as well as a CD including two ADR video examples. Beginning from the first ADR classroom sessions, the classrooms were visited by the researchers weekly and parents were visited in their homes during the first, third, and seventh weeks to be observed and provided feedback in order to improve their ADR skills. Following the pretests and the trainings, the ADR was initiated for all treatment groups. The ADR treatment conditions are explained below:

Whole Group ADR - WG: Teachers conducted ADR only as a whole-class activity three days per week.

Whole \& Small Group ADR - WSG: Small group ADR was implemented along with the whole group ADR in the classroom. The teacher divided children into groups of 5-6, depending on the classroom size. While the teacher was working with one of the groups, others were directed to engage in different activities like painting and drawing. All children attended the small group condition once a week. Teachers carried out whole group ADR twice a week and 
small group ADR on the remaining three days.

Whole Group \& Home Based ADR - WGH: Home based ADR was implemented by parents at home along with the whole group ADR in the classroom. Parents conducted ADR with the same book of the week with their children three days a week, including the activities found in the activity booklets in the remaining four days.

Whole \& Small Group \& Home Based ADR - WSGH: This was the most intensive treatment condition including both the classroom based whole and small group implementation of ADR and home based ADR.

Home Based ADR - H: Children were exposed to ADR only at home. Parents read the book of the week with their children three days a week and performed the activities found in the activity booklets in the remaining days.

Control - C: No treatment was given and children underwent routine book reading activities that is, the teacher read-aloud with the whole class 4 times a week with each lasting around 10-15 minutes with different books chosen by the teacher during each read-aloud. A different book was selected for each reading. A typical read-aloud in the control condition included a few questions asked by the teacher before and after reading but no interaction facilitated during reading.

All teachers and parents in the five ADR conditions were asked to keep weekly logs of their reading and related literacy activities. These logs were collected during the classroom and home visits. Posttest assessments were conducted following completion of the intervention program. All measures used in the pretest were repeated at posttest. However, the Phonological Awareness Test was administered to children only at posttest due to certain problems during the course of the test development process which prevented its use during pretest. The tool was also not administered to children in the Whole \& Small Group at posttest due to their teacher's absence during the testing period.

\subsection{Data Analysis}

All pre- and posttest data were analyzed using SPSS 17.0 for Windows. Reliability analyses for data entry accuracy included a random selection of $25 \%$ of the data and results revealed a 99\% accuracy rate in rescoring and $100 \%$ accuracy rate in re-entry. Descriptive statistics were calculated, along with one-way analysis of variance (ANOVA) and analysis of covariance (ANCOVA) for possible between-group differences across the treatment conditions. As randomness was not considered for group selection in this study, the pretest results of the measures used in the study were taken as control variables in ANCOVA which is a statistical analysis to control systematic bias and decrease error variance or within group variance. Tests of normality, homogeneity of variance, and homogeneity of slopes were made to assure that assumptions of ANCOVA were met for each of these variables. A Shapiro-Wilks test was used to determine whether the groups were normally distributed. Tests of homogeneity of variance and homogeneity of slopes were computed for the groups that were found normally distributed. When all three assumptions were met, an ANCOVA was used. A mixed design ANOVA was conducted for those that did not meet the assumption for homogeneity of slopes and a single factor ANOVA was used for the phonological awareness scores which had not been tested during the pretest. LSD post-hoc tests were used for pairwise comparisons. Effect sizes were also examined by computing omega square $\left(\mathrm{GD}^{2}\right)$ in ANCOVA and partial eta square $(\eta 2)$ in ANOVA. The values of $.01, .06$, and .14 were accepted as cutoff points for small, medium and large effect sizes, respectively (Green \& Salkind, 2005).

\section{Results}

\subsection{Effects of ADR on Child Language Skills}

The pre- and posttest child language performances using TELD and TERVT are summarized in Table 3. As shown in the table, with the exceptions of a decrease at posttest by the WSG condition in the TERVT Receptive and Expressive Language and the $\mathrm{C}$ condition in the TELD Receptive Language and TERVT Expressive Language, all groups displayed an improved performance from pre- to posttest.

An ANCOVA was conducted to determine whether there were significant differences among the ADR treatment conditions and the control condition on the posttest language measures. In the analysis, children's TELD and TERVT pretest scores were used as the covariate to control the effects of group differences prior to ADR on posttest measures. The analyses showed that although the ADR groups did not differ significantly from C in the TELD Receptive Language and TERVT Receptive Vocabulary, the WG and H groups displayed a significantly higher performance on TELD Expressive Language, and H, WGH, and WSGH groups displayed a significantly higher performance on TERVT Expressive Vocabulary than the C group. Groups' means and adjusted means on the posttests of TELD and TERVT Receptive and Expressive Language, the results of ANCOVA, and adjusted mean differences between groups are summarized in Table 3 .

An ANCOVA was also conducted to determine whether there were significant differences among the ADR groups on child language scores. The results showed that while groups did not differ significantly on TELD Receptive Language, the WG and $\mathrm{H}$ groups displayed a significantly higher performance than the other ADR groups on TELD Expressive 
Language. In addition, all ADR groups performed significantly better than the WSG on TERVT Receptive and Expressive Vocabulary and H group also performed significantly better than WG on TERVT Expressive Vocabulary. The effect sizes of group differences indicated that the strength of the relationship between children's language performance and intervention condition was weak on TERVT Receptive Vocabulary (.04) but stronger on TELD Expressive Language and TERVT Expressive Vocabulary (.09). Results suggest that the program was more effective on expressive language compared to receptive language.

Table 3. Pre-and Posttest Means and Standard Deviations and Results of ANCOVA on TELD and TERVT Receptive and Expressive Language and Adjusted Mean Differences by Group

\begin{tabular}{|c|c|c|c|c|c|c|c|c|c|c|c|c|c|}
\hline \multirow[b]{2}{*}{ Group } & \multirow[b]{2}{*}{$n$} & \multirow[b]{2}{*}{$\begin{array}{l}\text { Pre } \\
\text { Mean }\end{array}$} & \multirow[b]{2}{*}{$\begin{array}{l}\text { Pre } \\
\text { sd }\end{array}$} & \multirow[b]{2}{*}{$\begin{array}{l}\text { Post } \\
\text { Mean }\end{array}$} & \multirow[b]{2}{*}{$\begin{array}{l}\text { Post } \\
\text { sd }\end{array}$} & \multirow{2}{*}{$\begin{array}{l}\text { Post } \\
\text { Adjusted } \\
\text { Mean }\end{array}$} & \multirow[b]{2}{*}{$F$} & \multirow[b]{2}{*}{$\omega^{2}$} & \multicolumn{5}{|c|}{ Groups' Adjusted Means Differences } \\
\hline & & & & & & & & & WSG & WGH & WSGH & $\mathrm{H}$ & $\mathrm{C}$ \\
\hline \multicolumn{14}{|c|}{ TELD Receptive Language } \\
\hline WG & 14 & 99.00 & 10.66 & 105.14 & 7.53 & 104.72 & \multirow{6}{*}{1.96} & \multirow{6}{*}{.03} & 5.95 & 0.95 & 1.68 & 1.18 & 7.74 \\
\hline WSG & 20 & 94.33 & 9.59 & 96.70 & 10.58 & 98.76 & & & -- & -5.01 & -4.28 & -4.78 & 1.78 \\
\hline WGH & 24 & 102.25 & 14.08 & 105.79 & 13.44 & 103.77 & & & & -- & 0.73 & 0.23 & 6.79 \\
\hline WSGH & 13 & 102.57 & 11.24 & 105.31 & 6.74 & 103.04 & & & & & -- & -0.51 & 6.06 \\
\hline $\mathrm{H}$ & 18 & 92.06 & 13.22 & 100.67 & 11.76 & 103.55 & & & & & & -- & 6.56 \\
\hline $\mathrm{C}$ & 16 & 98.78 & 11.62 & 97.56 & 10.73 & 96.99 & & & & & & & -- \\
\hline \multicolumn{14}{|c|}{ TELD Expressive Language } \\
\hline$\overline{\mathrm{WG}}$ & 14 & 93.13 & 6.57 & 104.14 & 5.93 & 106.93 & \multirow{6}{*}{$4.09 * *$} & \multirow{6}{*}{.09} & $7.30 * *$ & $5.06^{*}$ & $6.15^{*}$ & -0.14 & $7.31 * *$ \\
\hline WSG & 20 & 95.62 & 7.51 & 98.00 & 6.53 & 99.63 & & & -- & -2.25 & -1.15 & $-7.44 * *$ & 0.01 \\
\hline WGH & 24 & 102.54 & 10.73 & 104.33 & 11.21 & 101.88 & & & & -- & 1.09 & $-5.19^{*}$ & 2.25 \\
\hline WSGH & 13 & 102.00 & 6.48 & 102.69 & 6.76 & 100.78 & & & & & -- & $-6.28 *$ & 1.16 \\
\hline $\mathrm{H}$ & 18 & 98.22 & 11.23 & 107.17 & 9.21 & 107.07 & & & & & & -- & $7.44 * *$ \\
\hline $\mathrm{C}$ & 16 & 96.83 & 7.09 & 98.75 & 7.39 & 99.62 & & & & & & & -- \\
\hline \multicolumn{14}{|c|}{ TERVT Receptive Language } \\
\hline WG & 14 & 103.43 & 13.38 & 112.43 & 10.53 & 117.42 & \multirow{6}{*}{$2.84 *$} & \multirow{6}{*}{.04} & $9.12 * *$ & 0.07 & 3.93 & 0.85 & 4.27 \\
\hline WSG & 14 & 107.24 & 17.49 & 107.00 & 13.32 & 108.30 & & & -- & $-9.06 * *$ & -5.20 & $-8.27 * *$ & -4.85 \\
\hline WGH & 22 & 117.39 & 9.83 & 122.45 & 12.81 & 117.36 & & & & -- & 3.87 & 0.78 & 4.20 \\
\hline WSGH & 14 & 117.36 & 7.96 & 118.79 & 10.01 & 113.49 & & & & & -- & -3.08 & 0.34 \\
\hline $\mathrm{H}$ & 18 & 107.83 & 12.01 & 114.83 & 13.14 & 116.57 & & & & & & -- & 3.42 \\
\hline $\mathrm{C}$ & 18 & 105.21 & 10.42 & 109.44 & 11.77 & 113.16 & & & & & & & -- \\
\hline \multicolumn{14}{|c|}{ TERVT Expressive Language } \\
\hline$\overline{\mathrm{WG}}$ & 15 & 107.47 & 10.07 & 108.53 & 10.47 & 110.31 & \multirow{6}{*}{$6.87 * *$} & \multirow{6}{*}{.09} & $6.56^{* *}$ & -2.35 & -3.02 & $-6.06^{*}$ & 2.08 \\
\hline WSG & 14 & 108.35 & 15.75 & 102.43 & 12.21 & 103.75 & & & -- & $-8.91 * *$ & $-9.58 * *$ & $-12.6^{* *}$ & -4.48 \\
\hline WGH & 22 & 117.39 & 12.93 & 117.91 & 9.97 & 112.66 & & & & -- & -0.68 & -3.71 & $4.43^{*}$ \\
\hline WSGH & 14 & 113.00 & 7.56 & 115.71 & 9.28 & 113.33 & & & & & -- & -3.03 & $5.10^{*}$ \\
\hline $\mathrm{H}$ & 18 & 106.39 & 11.56 & 113.78 & 12.42 & 116.37 & & & & & & -- & $8.14 * *$ \\
\hline $\mathrm{C}$ & 18 & 106.37 & 11.75 & 105.06 & 12.11 & 108.23 & & & & & & & -- \\
\hline
\end{tabular}

\subsection{Effects of ADR on Child Print and Phonological Awareness Skills}

The pre- and posttest performances of groups on print awareness and phonological awareness are presented in Table 4 . Results demonstrated that with the exception of $\mathrm{C}$ obtaining the same mean in both pre- and posttest on print awareness, all groups increased their performance from pre- to posttest in both skill areas. A mixed design ANOVA was used to examine group differences on the Print Awareness Test. Since the phonological awareness test could only be used at posttest, a single factor ANOVA was preferred.

The results of mixed design ANOVA as summarized in Table 4 show that the WGH and WSGH groups obtained significantly higher scores than $\mathrm{C}$ in the Print Awareness Test,. In addition, results of ANOVA demonstrated that all intervention groups other than WSGH performed significantly better than $\mathrm{C}$ in the Phonological Awareness Test. The differences among the five ADR groups were also examined. It was found that WGH and WSGH groups obtained significantly higher scores than WSG and H groups on the Print Awareness Test. On the other hand, the results obtained from the Phonological Awareness Test showed that all ADR groups scored significantly higher than the WSGH group. Effect sizes for group differences indicated that the relationship between children's performances and the group factor was moderate in the Print Awareness Test (.09) and strong in the Phonological Awareness Test (.46).

Taken together, it should be noted that ADR practices including home based intervention were more effective in language, print, and phonological awareness skills than the only-classroom based ADR conditions or traditional book reading practices. 
Table 4. Groups' Pre- and Posttest Performances and Results of ANOVA on Print and Phonological Awareness and Mean Differences by Group

\begin{tabular}{|c|c|c|c|c|c|c|c|c|c|c|c|c|}
\hline \multirow[b]{2}{*}{ Group } & \multirow[b]{2}{*}{$n$} & \multirow{2}{*}{$\begin{array}{l}\text { Pre } \\
\text { Mean }\end{array}$} & \multirow{2}{*}{$\begin{array}{l}\text { Pre } \\
\text { sd }\end{array}$} & \multirow{2}{*}{$\begin{array}{l}\text { Post } \\
\text { Mean }\end{array}$} & \multirow{2}{*}{$\begin{array}{l}\text { Post } \\
\text { sd }\end{array}$} & \multirow[b]{2}{*}{$F$} & \multirow[b]{2}{*}{$\eta 2$} & \multicolumn{3}{|c|}{ Groups' Means Differences } & \multirow[b]{2}{*}{$\mathrm{H}$} & \multirow[b]{2}{*}{$\mathrm{C}$} \\
\hline & & & & & & & & WSG & WGH & WSGH & & \\
\hline \multicolumn{13}{|c|}{ Print Awareness } \\
\hline$\overline{\mathrm{WG}}$ & 15 & 10.73 & 2.02 & 11.33 & 2.31 & \multirow{6}{*}{$2.80^{*}$} & \multirow{6}{*}{.09} & 1.07 & -0.39 & -0.59 & -0.98 & 1.06 \\
\hline WSG & 14 & 9.63 & 2.31 & 10.26 & 2.28 & & & -- & $-1.46^{*}$ & $-1.66^{*}$ & -0.09 & -0.01 \\
\hline WGH & 22 & 10.50 & 2.45 & 11.73 & 1.16 & & & & -- & -0.19 & $1.37^{*}$ & $1.45^{*}$ \\
\hline WSGH & 14 & 10.86 & 2.28 & 11.93 & 1.18 & & & & & -- & $1.57^{*}$ & $1.65^{*}$ \\
\hline $\mathrm{H}$ & 18 & 9.47 & 1.81 & 10.35 & 1.79 & & & & & & -- & 0.08 \\
\hline $\mathrm{C}$ & 18 & 10.27 & 2.37 & 10.27 & 2.61 & & & & & & & -- \\
\hline \multicolumn{13}{|c|}{ Phonological Awareness } \\
\hline$\overline{\mathrm{WG}}$ & 15 & - & - & 14.20 & 4.13 & \multirow{5}{*}{$14.64 * *$} & \multirow{5}{*}{.46} & - & 2.16 & $7.56 * *$ & 2.30 & $9.84 * *$ \\
\hline WGH & 24 & - & - & 12.04 & 5.37 & & & - & -- & $5.40 * *$ & 0.14 & $7.68 * *$ \\
\hline WSGH & 14 & - & - & 6.64 & 2.27 & & & - & & -- & $-5.26^{*}$ & 2.28 \\
\hline $\mathrm{H}$ & 17 & - & - & 11.90 & 2.03 & & & - & & & -- & $7.54 * *$ \\
\hline $\mathrm{C}$ & 18 & - & - & 4.36 & 2.38 & & & - & & & & -- \\
\hline
\end{tabular}

$*_{p}<.05 * * p<.01$

\subsection{Effects of ADR on Teacher and Parent Behaviors}

Teacher and parent ADR behaviors were observed before, during and after the program by using the ADR Behaviors Checklist. Prior to intervention, both teachers and parents showed very limited number of interactional behaviors before and after reading and nearly no interaction during reading. However, following the teacher trainings and performance feedback provided by the researchers, teachers' explaining new words, initiating interactive talk, allowing children to speak, and repeating and expanding their talk increased at least 4 times. The teacher of WG was the one who demonstrated the greatest increase in ADR behaviors, while the teacher of WSG demonstrated the poorest. Although she was observed to initiate talk as much as other teachers in line with the directions given through ADR training, these mostly involved self-talk and she hardly allowed children to speak. In addition, the expressions she used and the questions she asked during repeated readings were by most similar with no day-to-day variations.

Post-intervention observations of parents revealed a significant difference in ADR behaviors compared to pre-intervention as well. Overall, parents in the $\mathrm{H}$ group displayed the highest increase in ADR behaviors, followed by those in the WGH group. Some of the ADR behaviors observed at the end of the program and mean frequencies by group are presented in Table 5.

Table 5. Frequencies of ADR Behaviors Demonstrated by Parents in ADR Groups

\begin{tabular}{|c|c|c|c|c|c|c|}
\hline \multirow[b]{2}{*}{ ADR Behavior } & \multicolumn{2}{|c|}{ WSGH } & \multicolumn{2}{|c|}{ WGH } & \multicolumn{2}{|c|}{$\mathrm{H}$} \\
\hline & Mean & $s d$ & Mean & $s d$ & Mean & $s d$ \\
\hline $\begin{array}{l}\text { Asks children open-ended questions about what the story } \\
\text { may be about by pointing out the title of the book and the } \\
\text { cover picture. }\end{array}$ & 1.88 & 0.64 & 1.58 & 0.61 & 2.67 & 0.83 \\
\hline Explains new vocabulary in the story. & 1.93 & 1.33 & 3.05 & 2.40 & 4.55 & 1.09 \\
\hline $\begin{array}{l}\text { Asks the children "who, what, where, when" and "why" } \\
\text { questions related to the story. }\end{array}$ & 2.43 & 0.85 & 9.62 & 3.06 & 8.14 & 2.71 \\
\hline $\begin{array}{l}\text { Asks the children to describe what is happening in a picture } \\
\text { in the book. }\end{array}$ & 1.62 & 0.77 & 5.30 & 3.20 & 4.89 & 2.08 \\
\hline $\begin{array}{l}\text { Asks open-ended prediction questions about the chain of } \\
\text { events and the end of the story. }\end{array}$ & 1.43 & 0.53 & 3.75 & 2.12 & 4.32 & 3.17 \\
\hline $\begin{array}{l}\text { Asks questions that make children relate the characters and } \\
\text { events of the story to their own lives. }\end{array}$ & 1.20 & 0.45 & 2.47 & 1.18 & 3.40 & 1.83 \\
\hline Repeats and expands children's responses. & 1.38 & 0.52 & 3.63 & 2.34 & 3.91 & 1.27 \\
\hline
\end{tabular}

\subsection{The Social Validity of ADR}

All participating adults were asked via the Social Validity Form whether they found ADR effective, whether they thought it would have a positive contribution to children's future reading skills and whether, they would continue using the ADR strategies, and recommend it to others. The responses on the 5-point scale revealed that all teachers fully agreed with the statements (point 5), with the exception of the teacher of WSG who rated all statements as " 4 ". Social validity data obtained from all 56 parents also showed that parents agreed with the statements at levels 4 and 5 , and only one parent in WPG expressed uncertainty with an agreement rating at level 3. Some parents, particularly those in groups that involved both home and classroom based ADR also indicated that their children sometimes got bored and did not want to read or talk about the book, as the same book was being read over and over again in the classroom and at home. 


\section{Discussion}

This study examined the effectiveness of the Adapted Dialogic Reading Program on the language and early literacy skills of children who were at-risk due to socio-economic disadvantages. Results demonstrated that the effects of ADR were apparent on children's expressive language as well as print and phonological awareness skills.

According to the findings, all but WSG showed significantly higher performance than $\mathrm{C}$ on expressive language and vocabulary posttest measures. However, they did not differ from $\mathrm{C}$ on receptive language and vocabulary. Despite several studies revealing that DR enhances both receptive and expressive language skills, findings indicating the effects of DR only on expressive language are more prevalent (Chow \& McBride-Chang, 2003; Hargrave \& Senechal, 2000; Lonigan \& Whitehurst, 1998; Mol et al., 2008; Wasik \& Bond, 2001), findings that are in better correspondence with our results.

The effect sizes found in this study for expressive language and vocabulary (.09) showed that ADR had a moderate effect on expressive language, a finding similar to that of Mol and colleagues' (2008) meta-analytic study. They indicated that moderate effect sizes were generally obtained in studies conducted with 3-4 year old children, and that as children got older (e.g. kindergarten age), the effect sizes partially decreased. Therefore, we can claim that the effect sizes found in our study, where the intervention took only seven weeks may be an indication that the effects of ADR are quite promising. In studies implementing ADR for longer periods of time, teachers and parents may become more competent in practicing the strategies and the effects of the program may increase dramatically.

In order to identify which treatment condition(s) was more effective on children's language skills, posttest group performances were compared controlling the effects of pretest scores. Overall, ADR in H and WG groups produced significantly higher language scores compared to the other three intervention groups. In H and WG groups, ADR was implemented in a single setting (home or classroom) under one condition (only whole group), whereas the other three were implemented more intensively in at least two settings (both home and classroom), or conditions (both in whole and small group in the classroom). Previous studies reported that the more intensive the program, the higher the performance of children in the targeted skills (e.g., Lonigan \& Whitehurst, 1998; Vally, 2012; Whitehurst, Arnold et al., 1994). The findings of this study however point to contradictory evidence, such that children who were exposed more to ADR scored comparatively lower than their peers in the less intensive treatment conditions. Teacher interviews also confirmed this finding. Teachers in the more intensive conditions stated that children got bored and lost their interest when they were read the same book at home and in the classroom, or both in small and whole groups in the classroom, and suggested a reduction in the frequency of the reading activities. These contradictory findings may be thought to be related with adult creativity in adult-child activities. During the pilot study, the researchers were well aware about the participant adults' lack of introducing engaging topics and activities to children during reading. That was the main reason for developing the activity booklets, with an assumption that parents and teachers would use those activities and materials to gradually increase their activity repertoires. However, along the way, the authors observed that teachers and parents strictly followed the activity booklets using the same types of prompts to initiate a talk or the same statements to expand children's responses in all reading sessions, particularly in the beginning of the study. They had difficulties following children's lead and adapting the examples in the activity booklets to children's interests and abilities. Perhaps, this was why children in these repetitive readings frequently lost interest and used expressions like "We already know this" or "We've already talked about this". These problems may be attributed to the fact that teacher and parent trainings were not as effective as aimed or that a 7-week intervention was too short for teachers and parents to become competent in ADR. As for child interest, Mol and colleagues (2008) claim that 5-6 year old children can internalize knowledge more quickly than younger children and thus dislike repetitions, which may explain the participant children's feelings of boredom stated above. Therefore, we can conclude that an ADR program in which longer and more intensive parent and teacher trainings are delivered with a focus on strategies to keep child's interest in books awake may increase the effects of intervention.

In addition, it is worth noting that the $\mathrm{H}$ group displayed a consistently higher performance among all ADR groups and performed significantly better in TERVT expressive vocabulary than WG. This finding shows that parent mediated ADR is more effective on vocabulary than teacher mediated ADR. Even though classroom based ADR may be expected to be more effective owing to the fact that it is ran by better educated people (in this case teachers) in a setting with many more materials (in this case the classroom), an adult-child one-to-one interaction may almost be impossible in a classroom environment (Hindman, Connor, Jewkes, \& Morrison, 2008; Lonigan \& Whitehurst, 1998). It is thought that personalization, focusing on the specific child's interests, providing more opportunities to talk and keeping the interaction to a level more consistent with the child's abilities play a significant role in achievement (Lonigan \& Whitehurst, 1998), an explanation which fits our findings.

In contrast to the higher performance displayed on average by the ADR groups, it was found that WSG's performance was rather low and in most cases did not differ from $\mathrm{C}$. This unforeseen finding is thought to be associated with the 
professional competence of the teacher. The observations during the study showed that the teacher seldom allowed children to talk, did most of the talking herself, and generally used monotonous and repetitive expressions and children often seemed to get bored. Data obtained from the Social Validity Form also revealed that the teacher agreed with the statements at a lower level compared to her colleagues. At the same time, she was a vocational high school graduate, the only teacher without a bachelor's degree who was working her last year before retirement. Her insufficient professional background, higher probability of experiencing job burnout and perhaps lack of motivation to work may have adversely affected the success of ADR in this group. As Gormly and Ruhl (2005) state, teacher competence is one of the most important determinants in effective DR practices. We cannot claim, on the basis of one individual teacher's performance that teacher competence was the sole reason for the group's poor performance. However, we may recommend to interested researchers to take into account this critical factor in their studies, perhaps by conducting their study with a larger sample of teachers.

Results of the posttest group comparisons in print and phonological awareness measures partially resembled those obtained on measures of language. The print awareness scores of children indicated that the highest performance was displayed by WGH and WSGH, while the lowest performance was displayed by C and WSG. On the other hand, phonological awareness scores of children indicated that the highest performance was displayed by the WG, WGH and H groups, while the lowest performance was displayed by the C and WSGH groups. Taken together, the results revealed that ADR had significant effects on both language and early literacy skills, and that parent involvement played an important role in improving these skills. Different from language measures, however, program intensity emerged as a determining factor in children's early literacy performance. ADR conducted both at home and the classroom promoted higher early literacy achievement. These results are comparable to those of previous studies. For instance, Whitehurst and colleagues (1994) examined the effectiveness of DR on children from low SES families, and concluded that children who were exposed to DR both at school and at home improved their vocabulary and language skills significantly more than those who were exposed to DR conducted only at school. In addition, Lonigan and Whitehurst (1998) found greater effects of DR on targeted skills for children who were read both by teachers and parents, followed by those who were read only by parents. Authors attributed higher performance of children in conditions involving home reading to both higher frequency of DR and one-to-one interaction between parent and child that allow for child ability level adjustments by the adult.

In sum, even though a significant improvement was not found in one ADR condition (WSG), the remaining ADR groups demonstrated greater improvement in their language and early literacy skills compared to $\mathrm{C}$. Informal conversations with the participant teachers and parents showed that the strategies taught in the study seemed quite new for them. Teachers stated that during their undergraduate education, they all were advised not to interrupt reading during read-alouds because it would distract children's attention from the story, and thus they felt the need to stick to this rule in their classroom practices. In addition, many parents that were interviewed made comments including "We didn't know that we were supposed to talk to our children and allow them to talk when reading and that learning new words would be a good thing for their future school success" and "I mostly didn't read with my child, and when we did, I would get upset at questions and tell my child to be quiet. This study showed me how wrong I was". On the other hand, many parents indicated the benefits of ADR with the following comments: "I wanted to do something to prepare my child for school and make her more successful, but I didn't know how. Now I know what I can do." or "We spend a great time while reading. I felt I didn't know about my child prior to these activities. These readings helped us get to know each other. Our relationship has changed since then and so has my child's speech. He forms better sentences and uses new words and this makes us very happy". These informal sources of information imply that ADR indeed has led to meaningful and positive changes in the lives of at least some of the participating children.

Despite the promising evidence on behalf of ADR on children's language and early literacy skills, the interpretation of our results is subject to several limitations that force us to consider them only preliminary. First of all, we cannot specify whether these are the best possible outcomes for kindergarteners from low SES backgrounds due to the fact that we do not have similar studies in Turkey to compare our results and claim whether ours were better or not. Although we tempted to tailor the principles of DR to Turkish kindergarteners, their parents and teachers, we still need further research to see the effects of alternative culture-specific practices before we can jump to conclusions about the best DR practices in Turkey for children from low SES populations.

Secondly, it's not clear whether DR will have continuing effects on children as they enter first grade, where higher levels of child language and literacy skills are required. Although studies conducted in other countries showed that DR have continuing effects in later years (e.g. Nelson, 2005; Snow et al., 1998; Spira et al., 2005; Vellutino et al., 2003), we cannot claim the same to be true for Turkish kindergarteners due to cultural differences. Therefore, the need for systematic investigation of longer term effects as children progress into higher grades in Turkey remains.

Thirdly, although child language measures used in this study were standardized, the lack of standardized early literacy 
measures in Turkey led us to develop informal tools to assess these skills. Therefore, further research is needed to investigate the validity and reliability of these measures to use with young children. Fourthly, given that participation in the program was voluntary, teachers' willingness to get involved in an unfamiliar process that demanded additional time and effort may indicate their motivation and competence to enhance their instruction which, in turn, may have contributed to increased child achievement. An important need in future research is to conduct follow up studies with controlling teacher effects when testing each ADR treatment condition across several classrooms. Given the positive effects of ADR, it is also critically important that future studies identify the factors that make it more likely that teachers will adopt ADR.

Fifth, although the numbers were sufficient to conduct parametric tests, the results should be cautiously considered on the basis of small sample size. In addition, assignment of children to the treatment conditions generated perhaps the most important limitation in this study. As explained in the Methods section, the random assignment procedure included the classrooms as a unit, instead of each individual child. However, such procedure would have made the gathering of children, parents, and teachers in the same intervention condition (who came from different classrooms) nearly impossible. Therefore we were actually forced by the conditions to apply this assignment procedure. Nevertheless, we would like to claim that, despite its threat to making generalizations, this procedure also yielded results pertaining to real life situations, where the classrooms and the teachers were the actual classrooms and the actual teachers with their actual physical and social dynamics.

The results obtained in this study are important in many respects for the field of early childhood education in Turkey. First, Turkey in recent years, has been trying to extend kindergarten education to include all children across the nation. Therefore, schools attract a growing number of children every year, and an important number of these children are considered at risk for academic failure in subsequent years. This requires teachers and programs to be equipped adequately to support the development of individual children with differing educational needs. Therefore, an instructional method that is effective, practical, and developmentally appropriate for achieving different instructional purposes may significantly contribute to the improvement of existing early childhood education programs in Turkey. Although our findings are only preliminary at this point, we find them as an important start-off for early literacy research and practice in Turkey. Thus we recommend the widespread dissemination of DR in existing programs in Turkey on the basis of a growing research on early literacy.

Secondly, the results of this study showed that ADR was most effective when parent involvement was ensured. Considering the social validity from the perspective of parents, it is crucial to introduce ADR to all parents and promote its use beginning from children's early years. Such an effort will contribute tremendously to children's development by parents using better quality home literacy activities in more positive interactive environments. At this point, one topic is worthy of mention. Our study was conducted only with a low SES sample and our findings do not provide any evidence for what parents of children from other SES strata actually believe and do in their homes. Therefore we recommend future research to identify these factors comparatively across different SES strata.

Thirdly, literature shows that DR is effective not only in language and early literacy skills, but also in instilling a positive attitude in children towards reading (Kotaman, 2008; Sperling \& Head, 2002). There are also studies which revealed that children with a positive reading attitude display higher academic achievement in school (Kush, Watkins, \& Brookhart, 2005). In light of these findings, it is possible to state that continuous and proper use of ADR may have positive effects on children's reading attitudes which in turn may boost reading and academic achievement in general. Even though the present study did not evaluate children's attitudes towards books or reading, considering the social validity data, we believe that ADR also had positive effects on child and parent attitudes toward ADR. Thus, it is very important to employ ADR as an intervention program with children who are at risk due to negative environmental conditions, which most likely will play an important role in decreasing the potential learning problems they are likely to face in school and increasing their chances for success.

\section{Acknowledgements}

This research was supported by Grant 111K161 from The Scientific and Technological Research Council of Turkey.

\section{References}

Aarnoutse, C., Van Leeuwe, J., \& Verhoeven, L. (2005). Early literacy from a longitudinal perspective. Educational Research and Evaluation, 11, 253-275. http://dx.doi.org/10.1080/08993400500101054

Adams, M. J. (1990). Learning to read: Thinking and learning about print. Cambridge, MA: MIT Press.

Al Otaiba, S., Lewis, S., Whalon, K., Dyrlund, A., \& McKenzie, A. R. (2009). Home literacy environments of young children with Down syndrome: Findings from a web-based survey. Remedial and Special Education, 30, 96-107. http://dx.doi.org/10.1177/0741932508315050 
Arnold, D. H., Lonigan, C. J., Whitehurst, G. J., \& Epstein, J. N. (1994). Accelerating language development through picture-book reading. Journal of Educational Psychology, 86, 235-243. http://dx.doi.org/10.1037/0022-0663.86.2.235

Badian, N. A. (1995). Predicting reading ability over the long term: The changing roles of letter-naming, phonological awareness and orthographic processing. Annals of Dyslexia, 45, 3-25. http://dx.doi.org/10.1007/BF02648213

Beck, I. L., McKeown, M. G., \& Kucan, L. (2002). Bringing words to life: Robust vocabulary instruction. New York: Guilford Press.

Burns, M. S, Griffin, P., \& Snow, C. E. (Eds.) (1999). Starting out right: A guide to promoting children's reading success. Washington, DC: National Academy Press.

Bursuck, W., \& Damer, M. (2007). Reading instruction for students who are at risk or have disabilities. Boston, MA Pearson Education, Inc.

Cabell, S. Q., Justice, L. M., Konold, T. R., \& McGinty, A. S. (2011). Profiles of emergent literacy skills among preschool children who are at risk for academic difficulties. Early Childhood Research Quarterly, 26, 1-14. http://dx.doi.org/10.1016/j.ecresq.2010.05.003

Chow, B. W. Y., \& McBride, C. C. (2003). Promoting language and literacy development through parent-child reading in Hong Kong preschoolers. Early Education and Development, 14, 233-248. http://dx.doi.org/10.1207/s15566935eed1402_6

Chow, B. W. Y., McBride, C. C., \& Cheung, H. (2010) Parent-child reading in English as a second language: Effects on language and literacy development of Chinese kindergartners. Journal of Research in Reading, 33, 284-301. http://dx.doi.org/10.1111/j.1467-9817.2009.01414.x

Denton, K., \& West, J. (2002). Children's reading and mathematics achievement in kindergarten and first grade. (U.S. Department of Education, NCES 2002-125). Washington, DC: U.S. Government Printing Office.

Deretarla-Gül, E., \& Bal, B. (2006). Anasınıfı öğretmenlerinin okuma yazmaya hazırlık çalışmalarına ilişkin bakış açıları, sınıf içi kullanılan materyal ve etkinlikler ile çocukların okuma yazmaya ilgilerinin incelenmesi. Çocuk Gelişimi ve Ĕ̈itimi Dergisi, 1(2), 33-51.

Dickinson, D. K., \& McCabe, A. (2001). Bringing it all together: The multiple origins, skills and environmental supports of early literacy. Learning Disabilities Research and Practice, 16(4). 186-202. http://dx.doi.org/10.1111/0938-8982.00019

Ehri, L., Nunes, S., Stahl, S., \& Willows, D. (2001). Systematic phonics instruction helps students learn to read: Evidence from the National Reading Panel's meta-analysis. Review of Educational Research, 71, 393-447. http://dx.doi.org/10.3102/00346543071003393

Elliott, E., \& Olliff, C. (2008). Developmentally appropriate emergent literacy activities for young children: Adapting the Early Literacy and Learning Model (ELLM). Early Childhood Education Journal, 35, 551-556. http://dx.doi.org/10.1007/s10643-007-0232-1

Ergül, C., Akoğlu, G., Sarıca, A. D., Tufan, M., \& Karaman, G. (2015). Examination of shared book reading activities in kindergartens based on "Dialogic reading". Mersin University Journal of the Faculty of Education, 11(3), 603-619. http://dx.doi.org/10.17860/efd.88429

Ergül, C., Karaman, G., Akoğlu, G., Tufan, M., Sarıca, A. D., \& Bahap-Kudret, Z. (2014). Okul öncesi öğretmenlerinin "erken okuryazarlı" kavramına ilişkin bilgi düzeyleri ve sınıf uygulamaları. Illköğretim Online, 13(4), 1449-1472. http://dx.doi.org/10.17051/io.2014.71858

Evans, M. A., Bell, M., Shaw, D., Moretti, S., \& Page, J. (2006). Letter names, letter sounds and phonological awareness: An examination of kindergarten children and of letters across children. Reading and Writing, 19, 959-989. http://dx.doi.org/10.1007/s11145-006-9026-x

Ezell, H. K., \& Justice, L. M. (2000). Increasing the print focus of adult-child shared book reading through observational learning. American Journal of Speech Language Pathology, 9, 36-47. http://dx.doi.org/10.1044/1058-0360.0901.36

Farkas, G., \& Beron, K. (2004). The detailed age trajectory of oral vocabulary knowledge: Differences by class and race. Social Science Research, 33, 464-497. http://dx.doi.org/10.1016/j.ssresearch.2003.08.001

Farver, J. M., Nakamoto, J., \& Lonigan, C. J. (2007). Assessing preschoolers' emergent literacy skills in English and Spanish with the Get Ready to Read! Screening Tool. Annals of Dyslexia, 57, 161-178.

http://dx.doi.org/10.1007/s11881-007-0007-9

Fielding-Barnsley, R., \& Purdie, N. (2003). Early intervention in the home for children at risk of reading failure. 
Support for Learning: British Journal of Learning Support 18(2), 77-82. http://dx.doi.org/10.1111/1467-9604.00284

Gormley, S., \& Ruhl, K. L. (2005). Dialogic shared storybook reading: An instructional technique for use with young students in inclusive settings. Reading \& Writing Quarterly, 21, 307-313. http://dx.doi.org/10.1080/10573560591007353

Green, S. B., \& Salkind, N. J. (2005). Using SPSS for Windows and Macintosh: Analyzing and understanding data (4 ed.). Upper Saddle River: Pearson.

Gül, G. A., \& Kazak, B. S. (2010). Türkçe ifade edici ve alıcı dil testi. Ankara: Türk Psikologlar Derneği.

Hargrave, A. C., \& Senechal, M. (2000). A book reading intervention with preschool children who have limited vocabularies: The benefits of regular reading and reading. Early Childhood Research Quarterly, 15, 75-90. http://dx.doi.org/10.1016/S0885-2006(99)00038-1

Hart, B., \& Risley, T. (2003). The early catastrophe: The 30 million word gap by age 3. American Educator, 27(4), 6-9.

Hindman, A. H., Connor, C. M., Jewkes, A. M., \& Morrison, F. J. (2008). Untangling the effects of shared book reading: Multiple factors and their associations. Early Childhood Research Quarterly, 23, 330-350. http://dx.doi.org/10.1016/j.ecresq.2008.01.005

Horst J. S., Parsons K. L., \& Bryan N. M. (2011). Get the story straight: Contextual repetition promotes word learning from storybooks. Frontiers in Psychology, 2, 17-25. http://dx.doi.org/10.3389/fpsyg.2011.00017

Hresko, W. P., Reid, D. K., \& Hammill, D. D. (1999). Test of early language development (3rd edition). Austin: Pro-ed.

Hudson, M. E., \& Test, D. W. (2011). Evaluating the evidence base for using shared story reading to promote literacy for students with extensive support needs. Research and Practice for Persons with Severe Disabilities, 36, 34-45. http://dx.doi.org/10.2511/rpsd.36.1-2.34

Huebner, C. E. (2000). Community-based support for preschool readiness among children in poverty. Journal of Education for Students Placed At Risk, 5, 291-314. http://dx.doi.org/10.1207/S15327671ESPR0503_6

Justice, L. M., \& Ezell, H. (2002). Use of storybook reading to increase print awareness in at risk children. American Journal of Speech-Language Pathology, 11, 17-29. http://dx.doi.org/10.1044/1058-0360

Justice, L. M., \& Pullen, P. C. (2003). Promising interventions for promoting emergent literacy skills: Three evidence-based approaches. Topics in Early Childhood Special Education, 23, 99-113. http://dx.doi.org/10.1177/02711214030230030101

Justice, L. M., Kaderavek, J., Bowles, R. P., \& Grimm, K. J. (2005). Language impairment, parent-child shared reading, and phonological awareness: A feasibility study. Topics in Early Childhood Special Education, 25(3), 143-156. http://dx.doi.org/10.1177/02711214050250030201

Justice, L. M., Pullen, P. C., \& Pence, K. (2008) Influence of verbal and nonverbal references to print on preschoolers' visual attention to print during storybook reading. Developmental Psychology, 44, 855-866. http://dx.doi.org/10.1037/0012-1649.44.3.855

Kjeldsen, A. C., Karna, A., Niemi, P., Olofsson, A., \& Witting, K. (2014). Gains from training in phonological awareness in kindergarten predict reading comprehension in Grade 9. Scientific Studies in Reading, 18, $452-467$. http://dx.doi.org/10.1080/10888438.2014.940080

Kotaman, H. (2008). Impacts of dialogical storybook reading on young children's reading attitudes and vocabulary development. Reading Improvement, 45(2), 55-61. ERIC Document No: EJ1023501

Kush, J. C., Watkins, M. W., \& Brookhart, S. M. (2005). The temporal-interactive influence of reading achievement and reading attitude. Educational Research and Evaluation, 11, 29-44. ERIC Document No: EJ691547

Leppanen, U., Niemi, P., Aunola, K., \& Nurmi, J. E. (2006). Development of reading and spelling Finnish from preschool to grade 1 and grade 2. Scientific Studies of Reading, 10(3), 3-30. http://dx.doi.org/10.1207/s1532799xssr1001_2

Lesiak, J. L. (1997). Research-based answers to questions about emergent literacy in kindergarten. Psychology in Schools, 34, 143-160. http://dx.doi.org/10.1002/(SICI)1520-6807(199704)

Lever, R., \& Senechal, M. (2011). Discussing stories: On how a dialogic reading intervention improves kindergartners' oral narrative construction. Journal of Experimental Child Psychology, 108(1), 1-24.

http://dx.doi.org/10.1016/j.jecp.2010.07.002 
Liu, P. D., McBride-Chang, C., Wong, A. M., Tardif, T., Stokes, S. F., \& Fletcher, P., et al. (2010). Early oral language markers of poor reading performance in Hong Kong Chinese children. Journal of Learning Disabilities, 43, 322-331. http://dx.doi.org/10.1177/0022219410369084

Lonigan, C. J., \& Whitehurst, G. J. (1998). Examination of the relative efficacy of parent and teacher involvement in a shared-reading intervention for preschool children from low-income backgrounds. Early Childhood Research Quarterly, 13, 263-290. http://dx.doi.org/10.1016/S0885-2006(99)80038-6

McCardle, P., Scarborough, H. S., \& Catts. H. W. (2001). Predicting, explaining, and preventing reading difficulties. Learning Disabilities Research and Practice, 16, 230-239. http://dx.doi.org/10.1111/0938-8982.00023

McLeod A. N., \& McDade H. L. (2011). Preschoolers' incidental learning of novel words during storybook reading. Clinical Research Preschool, 32, 256-266. http://dx.doi.org/10.1177/1525740109354777

Mol, S. E., Bus, A. G., de Jong, M. T., \& Smeets, D. J. H. (2008). Added value of dialogic parent-child book readings: A meta-analysis. Early Education and Development, 19(1), 7-26. http://dx.doi.org/10.1080/10409280701838603

Morgan, P., \& Meier, C. R. (2008). Dialogic reading's potential to improve children's emergent literacy skills and behavior. Preventing School Failure, 52(4), 11-16. http://dx.doi.org/10.3200/PSFL.52.4.11-16

National Association for the Education of Young Children-NAEYC (2009). Developmentally appropriate practice in early childhood programs serving children from birth through age 8. Retrieved March 10, 2015 from http://www.naeyc. org/about/positions/pdf/PSDAP.pdf

National Early Literacy Panel (2009). Developing early literacy: A scientific synthesis of early literacy development and implications for intervention. Washington, DG: National Institute for Literacy.

Nelson, P. A. (2005). Could you and your students use a poetry getaway? The Reading Teacher, 58, 771-773. http://dx.doi.org/10.1598/RT.58.8.7

Niklas, F., \& Schneider, W. (2013). Home literacy environment and the beginning of reading and spelling. Contemporary Educational Psychology, 38, 40-50. http://dx.doi.org/10.1016/j.cedpsych.2012.10.001

Pullen, P. C., \& Justice, L. M. (2003). Enhancing phonological awareness, print awareness, and oral language skills in preschool children. Intervention in School and Clinic, 39, 87-98. http://dx.doi.org/10.1177/10534512030390020401

Reese, E., Leyva, D., Sparks, A., \& Grolnick, W. (2010). Maternal elaborative reminiscing increases low-income children's narrative skills relative to dialogic reading. Early Education and Development, 21, 318-342. http://dx.doi.org/10.1080/10409289.2010.481552

Ren, L., \& Hu, G. (2011). A comparative study of family social capital and literacy practices in Singapore. Journal of Early Childhood Literacy, 13, 98-130. http://dx.doi.org/10.1177/1468798411429934

Robbins, C., \& Ehri, L. C. (1994). Reading storybooks to kindergartners helps them learn new vocabulary words. Journal of Educational Psychology, 86, 54-64. http://dx.doi.org/10.1037/0022-0663.86.1.54

Senechal, M. (1997). The differential effect of storybook reading on preschoolers' acquisition of expressive and receptive vocabulary. Journal of Child Language, 24, 123-138. http://dx.doi.org/10.1017/S0305000996003005

Senechal, M., \& Cornell, E. H. (1993). Vocabulary acquisition through shared reading experiences. Reading Research Quarterly, 28, 360-374. http://dx.doi.org/10.2307/747933

Senechal, M., Thomas, E., \& Monker, J. (1995). Individual differences in 4-year-old children's acquisition of vocabulary during storybook reading. Journal of Educational Psychology, 87, 218-229. http://dx.doi.org/10.1037/0022-0663.87.2.218

Senechal, M., LeFevre, J., Thomas, E., \& Daley, K. (1998). Differential effects of home literacy experiences on the development of oral and written language. Reading Research Quarterly, 32, 96-116. http://dx.doi.org/10.1598/RRQ.33.1.5

Snow, C. E., Burns, M. S., \& Griffin, P. (Eds.). (1998). Preventing reading difficulties in young children. Washington DC: National Academy Press.

Sperling, A. R., \& Head, M. D, (2002). Reading attitudes and literacy skills in prekindergarten and kindergarten children. Early Childhood Education Journal, 29, 233-236. http://dx.doi.org/10.1023/A:1015129623552

Spira, E. G., Bracken, S. S., \& Fischel, E. J. (2005). Predicting improvement after first-grade reading difficulties: The effects of oral language, emergent literacy, and behavior skills. Developmental Psychology, 41, 225-234. http://dx.doi.org/10.1037/0012-1649.41.1.225

Stadler, M. A., \& McEvoy, M. A. (2003). The effect of text genre on parent use of joint book reading strategies to 
promote phonological awareness. Early Childhood Research Quarterly, 18, 502-510. http://dx.doi.org/10.1016/j.ecresq.2003.09.008

Stevenson, J., \& Fredman, G. (1990). The social environmental correlates of reading ability. Journal of Child Psychology and Psychiatry, 5, 681-698. http://dx.doi.org/10.1111/j.1469-7610.1990.tb00810.x

Sulzby, E., \& Teale, W. (1991). Emergent literacy. In R. Barr, M. L. Kamil, P. B. Mosenthal, \& P. D. Pearson (Eds.), Handbook of reading research, Vol. 2 (727-757). New York: Longman.

Teale, W. H. (1986). Home background and young children's literacy development. In W. H. Teale and E. Sulzby (Eds.), Emergent literacy: Writing and reading. Norwood: Ablex.

Topbaş, S., \& Güven, O. S. (2011). Türkçe erken dil gelişimi testi. Ankara: Detay Yayıncılık.

Uzuner, Y. (1997, October). Filizlenen okur-yazarlık. Okul öncesi dönemde özel eğitim semineri. Ankara.

Vally, Z. (2012). Dialogic reading and child language growth - combating developmental risk in South Africa. South African Journal of Psychology, 42, 617-627. http://dx.doi.org/10.1177/008124631204200415

van Steensel, R. (2006). Relations between socio-cultural factors, the home literacy environment and children's literacy development in the first years of primary education. Journal of Research in Reading, 29, 367-382. http://dx.doi.org/10.1111/j.1467-9817.2006.00301.x

Vellutino, F. R., Scanlon, D. M., \& Lyon, G. R. (2000). Differentiating between difficult-to-remediate and readily remediated poor readers: More evidence against the IQ-achievement discrepancy definition of reading disability. Journal of Learning Disabilities, 33, 223-238. http://dx.doi.org/10.1177/002221940003300302

Verhoeven, L., \& Perfetti, C. A. (2011). Vocabulary growth and reading skill. Scientific Studies of Reading, 15(1), 1-7. http://dx.doi.org/10.1080/10888438.2011.536124

Walsh, B., \& Blewitt, P. (2006). The effect of questioning style during storybook reading on novel vocabulary acquisition of preschoolers. Early Childhood Education Journal, 33, 273-278. http://dx.doi.org/10.1007/s10643-005-0052-0

Wasik, B. A., \& Bond, M. A. (2001). Beyond the pages of a book: Interactive book reading and language development in preschool classrooms. Journal of Educational Psychology, 93, 243-250.

http://dx.doi.org/10.1037/0022-0663.93.2.243

Whitehurst, G. J., \& Lonigan, C. J. (1998). Child development and emergent literacy. Child Development, 69, 848-872. http://dx.doi.org/10.2307/1132208

Whitehurst, G. J., \& Lonigan, C. (2001). Emergent literacy: Development from prereaders to readers. In S. Neuman \& D. Dickinson (Eds.), Handbook of early literacy research (11-30). New York: Guilford.

Whitehurst, G. J., Arnold, D. S., Epstein, J. N., Angell, A. L., Smith, M., \& Fischel, J. E. (1994). A picture book reading intervention in day care and home for children from low-income families. Developmental Psychology, 30, 679-689. http://dx.doi.org/10.1037/0012-1649.30.5.679

Whitehurst, G. J., Epstein, J. N., Angell, A. L., Payne, A. C., Crone, D. A., \& Fischel, J. E. (1994). Outcomes of an emergent literacy intervention in Head Start. Journal of Educational Psychology, 86, 542-555. http://dx.doi.org/10.1037/0022-0663.86.4.542

Whitehurst, G. J., Falco, F. L., Lonigan, C., Fischel, J. E., DeBaryshe, B. D., Valdez-Menchaca, M. C., \& Caulfield, M. (1988). Accelerating language development through picture book reading. Developmental Psychology, 24, 552-558. http://dx.doi.org/10.1037/0012-1649.24.4.552

Yopp, H. K., \& Yopp, R. H. (2000). Supporting phonemic awareness development in the classroom. The Reading Teacher, 54, 130-143. http://dx.doi.org/10.1598/RT.54.2.2

This work is licensed under a Creative Commons Attribution 3.0 License. 